\title{
The Application of Life Skills in Sunnah: A Study Based on Recommended Life Skills by WHO
}

\author{
M. M. A. Abdullah ${ }^{1,}$, M. A. C. A. Fazlan ${ }^{2}$, M. I. F. Sheefa ${ }^{1} \&$ S. M. M. Mazahir ${ }^{1}$ \\ ${ }^{1}$ Department of Islamic Studies, South Eastern University of Sri Lanka, Sri Lanka \\ ${ }^{2}$ Department of Arabic Language, South Eastern University of Sri Lanka, Sri Lanka \\ *Correspondence: Department of Islamic Studies, South Eastern University of Sri Lanka, Oluvil, Sri Lanka. E-mail: \\ abdullahmma416@gmail.com
}

Received: September 21, 2020 Accepted: March 8, 2021 Online Published: July 12, 2021

doi:10.5430/wjss.v8n2p23 URL: https://doi.org/10.5430/wjss.v8n2p23

\begin{abstract}
Life skills refer to adaptive and positive behaviors that help people effectively cope with the needs and challenges of daily life. Thus, this study aimed at the analysis of the application of life skills in the Sunnah of Prophet (PBUH) based on the life skills recommended by WHO such as problem-solving, decision making, creative thinking, critical thinking, self-awareness, empathy, interpersonal relationship, effective communication, coping with stress, coping with emotions. The deductive content analysis of topic-related data in Hadith which refers to the verbal, action, and recognition of the Prophet $(\mathrm{PBUH})$, classic Islamic and modern literature, is conducted through the descriptive narrative method. The finding reveals the acknowledgment and the application of life skills on several occasions in Sunnah, as well as the adherence to such skills will assist walking through the guidance of Sunnah. As a result, it strongly suggests that the icon would serve as a guide for every individual in the modern world in terms of the effective application of life skills at various levels and circumstances that can assist in leading a successful life. This study will be referred for future studies regarding the application and the impact of life skills.
\end{abstract}

Keywords: life skills, Sunnah, Hadith, World Health Organization, WHO, Prophet Muhammed

\section{Introduction}

Life skills have been highlighted as an important resource for building psychosocial, emotional, cognitive, behavioral, and resilience skills in order to deal with everyday obstacles and participate productively in society (Nasheeda et al., 2019). These skills are found to be essential in negotiating and mediating issues that young people experience as they strive to become effective citizens (Prajapati et al., 2017).

The World Health Organization (2003, p. 3) defined life skills as, "the abilities for adaptive and positive behavior that enable individuals to deal effectively with the demands and challenges of everyday life". UNICEF defines life skills as "a behavior change or behavior development approach designed to address a balance of three areas: knowledge, attitude, and skills" (Rastogi, 2018, p. 6).

The relevance of life skills was highlighted in a comprehensive review of the literature. The ten fundamental life skills tactics and techniques are listed by UNICEF, UNESCO, and the WHO: problem-solving, critical thinking, effective communication skills, decision-making, creative thinking, interpersonal relationship skills, self-awareness building skills, empathy, and coping with stress and emotions (Priyadarshini, n.d. \& Ravindra, 2012).

These life skills constitute psychosocial capabilities and interpersonal skills that enable people to make healthy and productive decisions, solve problems, think critically, communicate effectively, develop good relationships, empathize with others, and manage the stresses and strains of life (Saravanakumar, 2020).

The goal of education, according to Islamic tradition, is to develop human beings holistically, taking into account their intellectual, spiritual, and moral growth (Eissa \& Khalid, 2019). It is noteworthy that more life improvement skills and techniques have been used in the Sunnah, specifically it points to the way of life that helps develop and apply life skills (Bukhari \& Iqbal, 2015). Scholars of Hadith define all words, actions, and recognitions, and moral characteristics that have come out of the Prophet Muhammed as Sunnah (Guraya, 1972). 


\section{Method}

For this study, deductive content analysis is applied because it is the most effective method for answering the research question: Which evidence of life skills did Prophet Muhammad display in his life? The data is based on the Sunnah, which includes the Prophet's statements, actions, characteristics, and mannerisms, as well as incidents from his life and how his companions perceived his behaviors. These sources are widely acknowledged among Muslims and are thought to be authentic since they were recorded by reputable Islamic scholars (Al-Mubarakpuri, 2002). This is supported by other Islamic literature as well as modern literature on life skills.

\section{Results and Discussion}

The life of the Prophet Muhammad (PBUH) was established on divine laws and principles, and it acts as a lighthouse not only for Muslims but for all mankind. His methods show how to organize daily routines in order to live a productive and balanced existence (Bukhari \& Iqbal, 2015). From the life of the Holy Prophet (PBUH), the following skills are mentioned:

\subsection{Problem Solving}

A problem is a situation in which someone wants to do something but is unsure of what to do immediately. In such a situation, problem-solving entails determining the most effective means of overcoming the issue. Thus, Problem-solving is the process of overcoming obstacles encountered when attempting to achieve a goal, and it necessitates the use of not only knowledge but also creativity and skills (Güleç, 2020).

According to Ravindra (2012), problem-solving skill assists us in dealing productively with problems in life. Significant problems that go unsolved can generate mental stress and physical hardship.

As in the case of the Alliance of Fudul, Prophet Muhammad (PBUH) was actively involved in problem-solving even before he became the last prophet at the age of forty. In the example of Hajar al-Aswad, he once again showed his problem-solving skill. He amicably handled this conflict with remarkable judgment. He laid the Stone on his cloak, which he had stretched out on the ground. He then asked each tribe's delegates to hoist the cloak together. He walked forward and laid the Black Stone in its position when it reached the proper height from the ground, so sharing equally in the honor and privilege of replacing it (Sulaiman et al., 2015).

Voss et al. (1983) pointed out that problem solving includes isolating the cause(s) of a problem and removing or at the very least limiting the effects. Hence, the unanimous acceptance of the prophet-suggested solution by Quraish and not causing other damages demonstrate the strength of his problem-solving skill.

Yet the ability to solve problems is a mental process, which includes finding, analyzing, and solving problems. The ultimate goal of solving the problem is to overcome obstacles and find solutions to problems that arose in daily life (Özreçberoğlu \& Çağanağa, 2018).

\subsection{Decision Making}

Decision-making is an activity that occurs in everyday activities. We make tiny decisions on a daily basis, but these decisions frequently have a big impact on our lives. An individual makes decisions about himself and his affairs, yet his decisions have an impact on others (Vrchota \& Švárová, 2015).

Colakkadioglu \& Celik (2016) point out that the decision-making process and the skills required for the effective management of this process can have an impact on an individual's life trajectory, life happiness, and social relationships.

The Treaty of Hudaybiyyah, which shines as a huge turning point for Muslims in history (Saritoprak, 2005) is one of the most striking incidents, focuses on life skills. The Treaty was a pivotal treaty between the Prophet Muhammad, representing the state of Medina, and the Quraysh tribe of Mecca at the end of the sixth year of the Hijra of the Prophet (Ismail, 2015). Furthermore, the treaty stands in Islamic history as an enduring masterpiece, revealing the Prophet's political skill and diplomacy (Shub et al., 2020).

However, two points in the treaty made it distasteful to some Muslims such as Umar bin al-Khattab, namely they were not given access to the Holy Sanctuary that year, and the seemingly humiliating attitude as regards reconciliation with the pagans of Quraish (Bukhari, 4189).

Even though the outcome of the agreement was detrimental to the Muslims and favorable to the Quraysh tribe on the surface, the effectiveness of the treaty includes the growth in the number of Muslims, weakness of the enemy thereafter, expansion in terrain propaganda and the maintenance of the dignity of women as well as the history 
reveals that the prophet's decision to sign the treaty led to the conquest of Mecca later (Saritoprak, 2005).

Although the incident showed a sense of confusion among some Muslims over the treaty, it is clear that the Prophet (PBUH) decided wisely and resourcefully in that difficult situation as this process emphasizes his decision-making skill.

\subsection{Creative Thinking}

The ability to reflect qualities of fluidity, flexibility, creativity, and elaboration can be defined as creative thinking. Learners will go through a range of steps in creative thinking, including synthesizing, building, planning the implementation of ideas, and applying them to produce something (Tohir et al., 2018).

Accordingly, the Prophet Mohammad (PHUB) played a creative role. He was able to start from the ground up and develop a Muslim society. He led people away from worshiping idols and toward worshiping one God, as well as away from battling one another toward developing a strong sense of unity and brotherhood among all. The Prophet was the portal through which a whole new human behavior system was revealed. The Prophet's initial Islamic community was creative and distinctive in nature, and that small society was to serve as the foundation for the great Islamic civilization that would follow (Al-Karasneh \& Saleh, 2010).

It is worth noting that the Prophet allowed his companions to show their skills and also gave them recognition. As the ruler of the Muslims, he convened an advisory group to establish a strategy for defending Madinah in the Battle of Ahzab. After a lengthy discussion among experts with sound advice, he agreed on the proposal of one of the Companion Salman Al-Farsi, to dig trenches as defense lines (Ibn Sa'd, 1990). This historical evidence indicates the appreciation of creative thinking by the Prophet (PHUB).

On attempting to break into Madinah, the enemies were surprised to see a wide trench and they realized that it is a new stratagem unknown in Arabia before, standing as an obstinate obstruction (Ibn Hisham, 1990). This incident further strengthens his creative approach.

Furthermore, the recognition of creativity in the life of the Prophet is evident from the adoption of the creative idea from the companion Habab Ibn al-Mundhir while choosing the location of the camp during the Battle of Badr (Ibn Al-Athir, 1994) and his appreciation of Sa'ad ibn Mu'ad when he made an idea for the formation of a special place for the Prophet in such situation (Ibn Ishaq, 2004). As life skills are essential for efficient functioning and innovation in daily life, the above evidence indicates the application of one of them in Sunnah.

\subsection{Critical Thinking}

According to Ravindra (2012), Critical thinking is the ability to objectively assess information and experiences. Critical thinking can help us notice and examine the elements that influence our attitudes and behavior, such as values, peer pressure, and the media, which can all contribute to our health.

Furthermore, critical thinking skill, according to Dahari et al. (2019), is an intellectually engaged and disciplined process. Conceptualization, application development, analysis, synthesis, and evaluation of information collected are all part of the process. For example, this sort of expertise is built on accuracy, precision, depth, consistency, and relevance. It refers to the goals, issues, assumptions, concepts, and empirical training that lead to conclusions, implications, and consequences, as well as the structure or element of implicit thought in all reasoning.

The importance of thinking was clearly stated in the Sunnah. Based on the writer's assessment of the sources of Prophet Tradition or Sunnah, Nordin \& Surajudeen (2015) point out an article about the barriers that prevent people from thinking critically. After referring to several hadiths, it concluded that the Prophet went to great lengths to teach his Companions in particular, and Muslims in general, how to avoid the obstacles that could prevent them from being critical thinkers. When the Prophet mentioned ijtihad or endorsed its application, he appeared to be referring to ijtihad as creative reasoning.

The Prophet has not only guided his companions to act according to his instructions but also taught them to act critically in daily affairs. Several historical incidents insist on the above-mentioned.

"Anas (ra) reported that Allah's Messenger occurred to pass by the people who were grafting trees. He then said, "If you don't do it, it might be good for you." (As a result, they stopped doing it), and the yield decreased. When he (the Holy Prophet) happened to be passing by, he said, "What is wrong with your trees?" They said, "You said this and that." He then replied, "You have greater knowledge (of a technical skill) in world affairs" (Sahih Muslim, 2363)

In the aforementioned prophetic guidance, it is evident that the Prophet has encouraged them to act critically instead of acting blindly in world affairs. 


\subsection{Self-awareness}

Self-awareness refers to one's knowledge of various aspects of the self, including its characteristics, behaviors, and feelings (Rochat, 2003). One's current behavior is based on his internal standards and values while his self-awareness is his external assessor (Duval \& Wicklund, 1972).

Alghamdi (2006) points out that the Sunnah encourages individuals to become aware of themselves, knowledgeable of their emotions, and completely recognize their feelings. Furthermore, Prophet Mohammad (PBUH) encourages Muslims to be aware of their feelings. He advises them to keep their bad emotions under control while intelligently expressing their positive emotions.

The following Prophetic tradition should be identified as one of the examples focusing on this aspect.

"Waabisah bin Ma'bad (ra) said: I approached Allah's Messenger (saw) and he said to me, "Come close, O Waabisah," so I got closer to him until my knee touched his knee. "O Waabisah, shall I tell you what you have come to ask me about?" he asked. Waabisah answered, "Tell me, O Allah's Messenger" (saw). 'Would you like to ask me about virtue and sin?' he said. 'Yes,' I said, and he continued, 'Question your heart.' Virtue is that by which the soul enjoys repose and the heart tranquility. Sin is what introduces trouble into the soul and tumult into man's bosom, whatever fatwas people may give you" (Musnad Ahmad, 18028).

There are two important points to be observed in this Prophetic guidance. The Prophet's answer to "Question your heart" and the explanation that "Sin is what introduces trouble into the soul" indicates the need and the importance of self-awareness. That is, the Prophet has established a bond between self-determination and self-awareness by guiding us through questioning our hearts. Moreover, He has highlighted that the nature of sin can make a self-aware person feel in the heart. Accordingly, the evidence of the above Sunnah shows that self-awareness is essential for success in daily life routine.

\subsection{Empathy}

According to Ravindra (2012), empathy is the ability to imagine what another person's life is like. Empathy can aid in the acceptance of individuals who are extremely different from us. This can help social relationships, particularly where there is ethnic or cultural diversity. Empathy can also stimulate nurturing behavior toward persons in need of care and assistance, as well as tolerance, as in the case of AIDS patients or people with mental disorders, who may be stigmatized and ostracized by the very people they depend upon for support.

Empathy, according to Varker \& Devilly (2007) involves the following invariant stages: (a) emotional recognition: the ability to discriminate another person's emotional state; (b) perspective-taking: the ability to see situations from another's perspective; (c) emotion replication: vicarious replication of the observed emotion; and (d) response decision: the outcome that is based on the feelings experienced. As a result, this process necessitates both affective and cognitive empathetic responses, as well as self-awareness and the ability to distinguish one's own experiences from those of others (More, 1996).

The Sunnah includes many sayings that focus on empathy and social awareness.

"The believers in their mutual kindness, compassion and sympathy are just like one body. When one of the limbs suffers, the whole body responds to it with wakefulness and fever" (Bukhari, 6011). It is evident from the verse "When one of the limbs suffers, the whole body responds to it with wakefulness and fever" that the believers of God understand the feelings of others.

Likewise, the following prophetic guidance can be cited as an additional example of how the Prophet has approached daily life.

"Narrated Umamah: A young man approached the Prophet and said, "O Allah's Messenger! Permit me to engage in Zina (illegal sex)." People encircled him and rebuked him, screaming things like, "Put an end to it! Stop!" However, the Prophet said, "Come close". The young man approached him, and he said, "Sit down", so he did. "Would you like it (unlawful sex) for your mother?" the Prophet asked, he said "No, may I be ransomed for you, by Allah". "Neither do the people like it for their mothers", the prophet replied. "Would you like that for your daughter?" the Prophet asked, he said "No, may I be ransomed for you, by Allah". Neither do the people like it for their daughters" the prophet replied. "Would you like that for your sister?" the Prophet asked, he said "No, may I be ransomed for you, by Allah". "Neither do the people like it for their sisters" the prophet replied. "Would you like that for your paternal aunt?" the Prophet asked, he said "No, may I be ransomed for you, by Allah". "Neither do the people like it for their paternal aunts" the prophet replied. "Would you like it for your maternal aunt?" the Prophet asked", he said "No, may I be ransomed for you, by Allah". "Neither do the people like it for their aunts" the prophet replied. The Prophet 
then placed his hand on him and prayed to Allah, saying, "O Allah, pardon his sin, purify his heart, and protect his chastity." After that, the young man never paid attention to anything related to that nature" (Musnad Ahmad, 501).

In the above Hadith, it became clear that the Prophet (PHUB) wanted to empower rather than destroy the young man with this compassionate, empathetic, and persuasive approach. Rather than alienating or undermining him, he worked to strengthen and empower him in his fight against temptations.

Likewise, the Hadith "Narrated Jabir bin 'Abdullah: "When a funeral procession passed in front of us, the Prophet rose to his feet, and we rose to our feet as well. 'O Allah's Apostle! this is a Jewish funeral procession" we said. "Whenever you witness a funeral procession, you should stand up" he advised" (1311 Bukhari) and in another version of the Hadith the Prophet said, "Is it not a living being (soul)" (1312 Bukhari) demonstrates how the Prophet of Islam instills empathy in his followers for people of all races, religions, and faiths. He emphasized what empathy meant to them because they were under the impression that empathy only applied to Muslims, but he assured them that respect is extended to all funerals. Here's a logical question: if this much empathy is required even for the dead, what about the living? It's a clear message to create human interactions that respect all civilizations' common bonds (Alghamdi, 2006).

\subsection{Interpersonal Relationship}

Interpersonal skills are defined as an umbrella term. It refers to Goal-directed behaviors, including communication and relationship-building competencies, used in interpersonal interaction episodes characterized by complex perceptual and cognitive processes, dynamic verbal and nonverbal interaction exchanges, diverse roles, motivations, and expectancies (Hardjati \& Febrianita, 2019).

Rahman \& Olayiwola (1993) stated that because Islam is a complete code of life, it has established particular guidelines, norms, and regulations to govern all forms of interpersonal communication and relationships. Islam has provided principles and methods of interpersonal communication, human interaction, and the relationship between Muslims and non-Muslims through the Qur'an, and Sunnah in order to achieve peace, equality, brotherhood, and prosperity in this world, as well as pleasure of God in the hereafter.

Ahmad (2005) clearly explains the fact that Allah's Messengers have reformed human society on the basis of eternal ideals of righteousness, virtue, and justice is documented in history. They urged mankind to learn from the Divine Call's timeless teachings, and they gathered those who heeded the call under a new, unifying flag. Thanks to that unifying message, those who were once separated into groups, tribes, and other partisan camps and were after each other's blood, life, and honor became the best and most trusted of friends. Their union leads to the formation of a new, powerful community whose members, both men and women were kind and devoted to one another. They rewrote history and built a new society from the ground up.

The following Sunnah addresses the concern of the prophet regarding the development of interpersonal relationships as being a proper role model.

"Abu Huraira (ra) narrated: There was a villager named Zahir who brought gifts from the village and presented them to the Prophet. The Prophet said: "Zahir is our villager, we are his city dwellers". The Prophet loved him, and he was a geeky man. One day, when he was selling his goods in the market, the Prophet came and hugged him behind" (Musnad Al-Bazzar, 6922).

In this interesting conversation, the Prophet has guided us to build relationships with others by his good manners and behavior. He has also shown the acceptance of gifts, replace something better, and humor as ways to build a relationship. Hence, the overlaid incident practically takes place in order to create inter-personal relationships and build them effectively.

Furthermore, as Rahman \& Olayiwola (1993) explain that in interpersonal communication, human contact, and societal interactions, Prophet Muhammad has provided a bunch of rights to other human beings.

For an instance the following Hadith could be mentioned:

"Abu Huraira reported Allah's Messenger (PBUH) as saying "Six are the rights of a Muslim over another". It was said to him, "What are these, Allah's Messenger?". He then said, "When you see him, greet him; when he asks you to a feast, accept it." When he seeks your advice, give it to him, and when he sneezes and says, "All praise is due to Allah," you say Yarhamuk Allah (may Allah show kindness to you); and when he is ill, pay him a visit; and when he dies, follow his bier" (Muslim, 2162). 


\subsection{Effective Communication}

Asemanyi (2015) points out that Communication is an intentional process of two or more individuals expressing, receiving, and interpreting messages containing factual information, sentiments, ideas, and desires through shared symbols.

El-Garah et al. (2012) indicate that the history of the Prophet Muhammad's preaching era emphasized the importance of communication as it relates to the evolution of civilization over time. With those of his generation who had been raised with their own generational practices, he handled communication tactfully.

While Usman et al. (2019), elaborate on the fact that human communication has become an art as a result of the Prophet Muhammad's application of various efficient approaches, they enlight that the techniques such as purifying the intention, knowing the audience (target), talk when needed, narration, analogy, smiles, and jokes, showing anger with facial expressions, communicating using sign language are among the techniques he approached through, whether they were companions, nonbelievers, or dignitaries at the time.

Furthermore, the following Sunnah clearly describes the prophet's communication skill.

"Narrated Aishah (ra): The Messenger of Allah did not speak quickly as you do now, rather he would speak so clearly, unmistakably, that those who sat with him would memorize it" (Jami' al-Tirmidhi, 3639).

Additionally, Ibn al-Qayyim (1994, p. 175) says "The Prophet used to talk so clearly that if somebody wanted to count the number of his words, he could do so. It was not too quick to mind, nor were there gaps in the words to cause confusion. On contrary, his guidance was complete"

According to the above message, it is clear how the Prophet's communication skills were. This practice clearly explains how communication with others can be done efficiently and effectively. Communication cannot be alive if it is vague or confusing or can make others feel complicated. That is why the Prophet has applied communication skill clearly and perfectly.

\subsection{Coping with Stress}

Stress is any external incident or any internal drive that threatens to alter the organism's equilibrium. Stress is a situation or feeling that occurs when a person believes that demands are greater than his or her ability to mobilize personal and social resources (Bhargava \& Trivedi, 2018).

While Achour et al. (2016), state that many of the tactics and techniques in terms of coping with stress are said to have been employed successfully by Prophet Muhammad, the ideal role model for Muslims, and they are essentially instructed to follow Prophet Mohammed's footsteps in dealing with stress and life's hardships, and solving day-to-day problems, they point out that Prophet Muhammed directed Muslims to use a series of religious therapy treatments to deal with sadness, anxiety, and fear, which are all key components of stress. For example, he urged Muslims to read the Qur'an, emphasizing certain portions in particular, such as Chapters 113-114, which effectively exhorts believers to seek refuge in God Almighty and ask for His protection. These, according to them, are well-established anchors in today's therapy of neurosis, which stems from feelings of insecurity and powerlessness.

Additionally, the following prophetic guidance can be included for analysis of this life skill.

"You should ask Allah for all of your needs, even if the strap of your sandal breaks" (Shu'ab al-Iman, 1080).

Here it is possible to identify that the Prophet has put psychological preparation first even in facing a minor difficulty. That is, he has been given guidance to manage stressful events in life. This is called stress management in psychology. Accordingly, it is noteworthy that many of the prayers and good deeds in the Prophet's Sunnah have been constructively handled to help manage and mental pressure.

\subsection{Coping with Emotions}

Alghamdi (2006) argues that emotional management skills are well supported by Sunnah. For example, it can be illustrated regarding self-control and self-management "Abu Huraira reported Allah's Messenger (PBUH) as saying: "The strong man is not one who can wrestle well, but the strong man is one who can control himself when he is enraged" (Bukhari, 6114).

Moreover, another notable prophetic practical guidance in this regard is as follows:

"Narrated Khabbab bin Al-Arat: We complained to Allah's Apostle about the persecution inflicted on us through the infidels. when he sat in the shadow of the Kaba, bending over his Burd (i.e. covering sheet). "Would you seek assistance for us?", "Would you pray for us to Allah?" we asked. "Among nations before you, a (believing) guy 
would be put in a trench built for him, a saw would be placed over his head, and he would be cut into two parts, but that (torture) would not make him give up his religion" he stated. By Allah, this religion (i.e. Islam) will be successful until a vacationer from Sana (in Yemen) to Hadrarmaut will worry none but Allah or a wolf as regards his sheep, however, you (people) are hasty" (Bukhary, 3612).

In the above hadith, the companion gives importance to the emotions as he continues the conversation with the Prophet. However, it is notable that the Prophet has managed the conversation through the strengthening of thought of that companion rather than pushing him through his emotions.

Moreover, many of the prophet's life events demonstrate the fact that, instead of acting merely based on emotions, he has properly managed them, in his decisions and events in life.

The following hadith also strengthens this statement:

"Abu Huraira reported it was said to Allah's Messenger (PHUB): Invoke the curse on the polytheists, to which he replied, "I have not been sent as the invoker of the curse, but as a mercy" (Muslim, 2599). It is evident from the above hadith that the Prophet has properly managed his feelings of anger and anxiety on several occasions of his life.

\section{Conclusion}

The article concludes that all ten life skills enumerated by World Health Organization could be found in Prophet Muhammed's life. Furthermore, it could be observed that, although the concepts and norms of life skills are indicated in Sunnah, its illustrations show that their application varies between each individual according to the difference in circumstances. Therefore, one's proper adherence to life skills will help him to walk through the guidance Sunnah. As a result, it firmly proposes the icon as a guide for each individual in the contemporary world regarding the effective application of life skills at various levels and occasions which may help towards leading a successful life.

\section{References}

Achour, M., Bensaid, B., \& Nor, M. R. B. M. (2016). An Islamic Perspective on Coping with Life Stressors. Applied Research in Quality of Life, 11(3), 663-685. https://doi.org/10.1007/s11482-015-9389-8

Ahmad, K. (2005). Foreword. In A. R. Siddiqui (Ed.), Inter Personal Relations An Islamic Perspective (pp. 1-49). Retrieved from https://islamicstudies.info/literature/Interpersonal_Relations.htm

Alghamdi, A. A. (2006). Role of Islamic educational values in developing emotional intelligence skills [Graduate Student Theses, Dissertations, \& Professional Papers. 4980, The University of Montana]. Retrieved from https://scholarworks.umt.edu/etd/4980

Al-Karasneh, S. M., \& Saleh, A. M. J. (2010). Islamic perspective of creativity: A model for teachers of social studies as leaders. Procedia - Social and Behavioral Sciences, 2(2), 412-426. https://doi.org/10.1016/j.sbspro.2010.03.036

Al-Mubarakpuri, S. (2002). Ar-Raheeq al-Makhtum = The sealed nectar: Biography of the noble prophet. Dar-us-Salam Publications.

Asemanyi, A. A. (2015). An Assessment of Students' Performance in Communication Skills: A Case Study of the University of Education Winneba. Journal of Education and Practice, 6(35), 1-7.

Bhargava, D., \& Trivedi, H. (2018). A Study of Causes of Stress and Stress Management among Youth. IRA-International Journal of Management \& Social Sciences (ISSN 2455-2267), 11(3), 108-117. https://doi.org/10.21013/jmss.v11.n3.p1

Bukhari, S. A. G., \& Iqbal, A. (2015). Daily Routine of the Holy Prophet (SAW). $A L-A z v \bar{a}, 30(44), 33-44$.

Colakkadioglu, O., \& Celik, D. B. (2016). The Effect of Decision-Making Skill Training Programs on Self-Esteem and Decision-Making Styles. Eurasian Journal of Educational Research, 65, 259-276. https://doi.org/10.14689/ejer.2016.65.15

Dahari, A. A., Suhid, A., \& Fakhrudin, F. (2019). Implementation Critical Thinking in Teaching Islamic Education. International Journal of Academic Research in Progressive Education and Development, 8(4), 805-823. https://doi.org/10.6007/ijarped/v8-i4/6756

Duval, S., \& Wicklund, R. A. (1972). A theory of objective self awareness. Academic Press. 
Eissa, M., \& Khalid, M. (2019). Development of Character and Life Skills through Islamic Methods of Teaching Acquired Science Subjects at Islamic International Schools in Malaysia. IIUM Journal of Educational Studies, 6(1), 3-17. https://doi.org/10.31436/ijes.v6i1.143

El-Garah, W., Beekun, R. I., Habisch, A., Lenssen, G., \& Adaui, L. (2012). Practical wisdom for management from the Islamic tradition. Journal of Management Development, 31(10), 991-100. https://doi.org/https://doi.org/10.1108/02621711211281906

Güleç, S. (2020). Problem Solving Skills in Social Studies Education and Problem Solving Skills of Social Studies Teachers. Journal of Education and Training Studies, 8(3), 48-55. https://doi.org/10.11114/jets.v8i3.4686

Guraya, M. (1972). The concept of Sunnah a historical study. Islamic Studies, 11(1), 13-44.

Hardjati, S., \& Febrianita, R. (2019). The Power of Interpersonal Communication Skill in Enhancing Service Provision. Journal of Social Science Research, 14, 3192-3199. https://doi.org/10.24297/jssr.v14i0.8150

Ibn Al-Athir, A. (1994). Usd al-ghabah fi marifat al-Sahabah [The Lions of the Forest and the knowledge about the Companions]. Dar al-Kutub al-Ilmiyya.

Ibn al-Qayyim, A.-J. (1994). Zad al-Ma'ad Fi Hadyi Khair Al 'Ibaad (27th ed.). Maktabat al-Manar al-Islamiyya.

Ibn Hisham, A. M. (1990). Sirat Ibn Hisham [Biography of the Prophet]. Dar al-Kutub al-Ilmy.

Ibn Ishaq, M. (2004). Al-Siyrat al-Nabawia [Biography of the Prophet]. Dar al-Kutub al-Ilmiyya.

Ibn Sa'd. (1990). Al-tabaqat al-Kubraa [major classes]. Dar al-Kutub al-Ilmiyya.

Ismail, M. (2015). The effectiveness of agreement Hudaybiya (Study of Conflict Resolution Method). Jurnal Ilmiah Peuradeun, 3(2), 295-310.

More, E. S. (1996). Empathy as a hermeneutic practice. Theoretical Medicine, 17(3), 243-254. https://doi.org/https://doi.org/10.1007/BF00489448

Nasheeda, A., Abdullah, H. B., Krauss, S. E., \& Ahmed, N. B. (2019). A narrative systematic review of life skills education: effectiveness, research gaps and priorities. International Journal of Adolescence and Youth, 24(3), 362-379. https://doi.org/10.1080/02673843.2018.1479278

Nordin, N., \& Surajudeen, A. T. (2015). Islamic Theoretical Model for Critical Thinking In Teaching and Learning of Islamic Education. GSE E-Journal of Education, 3, 34-44.

Özreçberoğlu, N., \& Çağanağa, Ç. K. (2018). Making it count: Strategies for improving problem-solving skills in mathematics for students and teachers' classroom management. Eurasia Journal of Mathematics, Science and Technology Education, 14(4), 1253-1261. https://doi.org/10.29333/ejmste/82536

Prajapati, R., Sharma, B., \& Sharma, D. (2017). Significance Of Life Skills Education. Contemporary Issues in Education Research, 10(1), 1-6.

Priyadarshini, H. (n.d.). Life skills building in Orphan and Vulnerable Children through Arts-based training programme. UNESCO. Retrieved from http://www.unesco.org/culture/en/artseducation/pdf/presentation204hemapriyadarshini.pdf

Rahman, A., \& Olayiwola, O. (1993). Interpersonal communication, human interaction and societal relationships in Islam. Africa Media Review, 7(3), 91-104.

Rastogi, N. (2018). Importance of Life Skills in Global Higher Education. Shanlax International Journal of Education, 6(1), 6-10.

Ravindra, H. N. (2012). Life Skills Approach - An Interactive Nursing Approach. IOSR Journal of Nursing and Health Science, 1(1), 29-32. https://doi.org/10.9790/1959-0112932

Rochat, P. (2003). Five levels of self-awareness as they unfold early in life. Consciousness and Cognition, 12, 717-731. https://doi.org/10.1016/S1053-8100(03)00081-3

Saravanakumar, A. R. (2020). Life skill education through lifelong learning. Lulu Publication.

Saritoprak, Z. (2005). An Islamic Approach to Peace and Nonviolence: A Turkish Experience. The Muslim World, 95(3), 413-427.

Shub, M. G., Shahroodi, M. reza, \& Ayazi, S. M. A. (2020). Political Negotiation, Principles, and Purposes: Rereading the Biography of the Holy Prophet of Islam (PBUH) (Case study: Treaty of Hudaybiyyah). Iranian 
Journal for the History of Islamic Civilization, 53(1), 7-32. https://doi.org/10.22059/jhic.2020.302593.654138

Sulaiman, A., Mohd Zarif, M. M., Mohd Nizah, M. A., Atoma, P., Ismail, A., \& Kandil, H. M. T. E. (2015). Creativity and innovation in Islam: It's necessity in Islamic education. The Social Sciences, 10(1), 61-66. https://doi.org/10.3923/sscience.2015.61.66

Tohir, M., Abidin, Z., Dafik, D., \& Hobri, H. (2018). Students creative thinking skills in solving two dimensional arithmetic series through research-based learning. Journal of Physics: Conference Series, 1008(1). https://doi.org/10.1088/1742-6596/1008/1/012072

Usman, A. H., Sailin, R., \& Abdul Mutalib, M. F. M. (2019). The prophetic arts of communication: Some reflections on humanity. Humanities and Social Sciences Reviews, 7(4), 377-384. https://doi.org/10.18510/hssr.2019.7449

Varker, T., \& Devilly, G. J. (2007). Types of empathy and adolescent sexual offenders. Journal of Sexual Aggression, 13(2), 139-149. https://doi.org/10.1080/13552600701661573

Voss, J. F., Greene, T. R., Post, T. A., \& Penner, B. C. (1983). Problem-Solving Skill in the Social Sciences. In G. H. Bower (Ed.), Psychology of Learning and Motivation (pp. 165-213). Academic Press. https://doi.org/https://doi.org/10.1016/S0079-7421(08)60099-7

Vrchota, J., \& Švárová, M. (2015). Comparison of decision-making skills of students and managers. Acta Universitatis Agriculturae et Silviculturae Mendelianae Brunensis, 63(3), 1073-1077. https://doi.org/10.11118/actaun201563031073

World Health Organization. (2003). Skills for health: skills-based health education including life skills: an important component of a child-friendly/health-promoting school. In WHO information series on school health: document 9. Retrieved from https://apps.who.int/iris/handle/10665/42818

\section{Copyrights}

Copyright for this article is retained by the author(s), with first publication rights granted to the journal.

This is an open-access article distributed under the terms and conditions of the Creative Commons Attribution license (http://creativecommons.org/licenses/by/4.0/). 